\title{
Evaluation of the effects of FYM and gypsum on onion (Allium cepa L.) production under sodic water irrigation
}

\author{
Amit Kumar, A. C. Yadav, Ansul, Vinod Kumar and Avtar Singh \\ Department of Vegetable Science, CCS Haryana Agricultural University, Hisar-125004 (Haryana), INDIA \\ *Corresponding author. E-mail: aluhach007@gmail.com
}

Received: February 9, 2016; Revised received: July 12, 2016; Accepted: October 24, 2016

\begin{abstract}
A field experiment was conducted at CCS Haryana Agricultural University, Hisar to study the effect of FYM and gypsum on onion (Allium cepa L.) production under sodic water irrigation. Treatments comprised of three levels of farm yard manure (FYM) ( $F_{0}-$ no $F Y M, F_{1}-10$ t/ha and $F_{2^{-}} 20$ t/ha $\left.F Y M\right)$ and three levels of gypsum ( $G_{0}-$ no gypsum, $\mathrm{G}_{1}-50 \%$ neutralization of $\mathrm{RSC}$ and $\mathrm{G}_{2-}-100 \%$ neutralization of $\mathrm{RSC}$ ) in addition to control (irrigation with sodic water and no FYM and no gypsum $F_{0} G_{0}$ ). Results of the study showed that the seedling mortality was maximum $(77.50 \%)$ in control $\left(F_{0} G_{0}\right)$ treatment, while minimum number of seedlings mortality $(18.17 \%)$ was observed in $\left(\mathrm{F}_{2} \mathrm{G}_{2}\right)$ treatment followed by $(25.17 \%)\left(\mathrm{F}_{2} \mathrm{G}_{1}\right)$ treatment. There was significant increase in growth and yield of onion with application of FYM and gypsum. Moreover, maximum bulb yield $\left(180.83 \mathrm{q} / \mathrm{ha}\right.$ ) was recorded in $\left(\mathrm{F}_{2} \mathrm{G}_{2}\right)$ followed by $F_{2} G_{1}(152.22 \mathrm{q} / \mathrm{ha})$ where $100 \%$ sodicity of water was neutralized by the application of gypsum and 20 t/ha $F Y M$. Under sodic water conditions, increasing level of gypsum and FYM help in reducing the sodicity of irrigation water and thereby, increasing the yield of onion. The study concluded that in present situation of scarcity of good quality water for agricultural purposes, use of amendments like FYM and gypsum were best alternative for the best possible use of poor quality ground water and simultaneously sustain the yield of vegetable crops like onion which are sensitive to sodic water.
\end{abstract}

Keywords: Farm yard manure, Gypsum, Onion yield, Sodic water

\section{INTRODUCTION}

Currently, India's share in the world's total vegetable production is $13.6 \%$ and demand for vegetables is projected to rise to 170 million tons by the year 2025 . Moreover, the per capita consumption of vegetables in our country is $135 \mathrm{~g} /$ day against the recommendation of 280 $\mathrm{g} /$ day (Anonymous, 2009). Onion is one of the most important vegetable crops grown throughout the world. India is the second largest producer of onion in the world after China. During 2012-13, area under onion cultivation is 10.64 lakh hectares with production of 151.18 lakh tonnes in India. In Haryana, the area under vegetable production is 0.28 million ha with an annual production of 3.3 million tons (Tiwari et al., 2013). The area and production of vegetables may be increased with proper management practices such as management of poor quality water. Good quality water is the most critical and scarce resource for drinking, agriculture and industry, more so in arid and semi-arid regions. The continuous increase in the human and animal population has resulted in increased demand of water for domestic, industrial and agriculture needs. Presently, about $15 \%$ of India's water resources are consumed to meet out the domestic and industrial requirements and share of these two sectors will grow to about $30 \%$ by 2050 (Minhas and Samra, 2004). In the arid and semi-arid tracts of Haryana, about $70 \%$ underground water is of poor quality from irrigation point of view. Of the total $70 \%, 20 \%$ is sodic, $14 \%$ saline and $36 \%$ saline-sodic. Because of the inadequate canal irrigation facilities, these water categories constitute either the major or the only source of irrigation. Continuous and indiscriminate use of sodic water for irrigation as such causes soil sodicity and at the same time, adversely affects the growth and yield of crops under most situations. Although lot of research work has been done on various field crops by using sodic water with amendments like farm yard manure (FYM) and gypsum, yet there is a lack of information on vegetable crops in general andonion crop in particular. Therefore, the present study was undertaken to study the effect of FYM and gypsum on onion (Alliumcepa L.) production under sodic water irrigation.

\section{MATERIALS AND METHODS}

The experiment was carried out at Vegetable Research Farm of CCS Haryana Agricultural University, Hisar during 2012-13 on an ongoing permanent experiment, which had been in progress since 1994. The soil of the experimental field was sandy loam Typic ustochrept having $19.6 \%$ clay and CEC $9.3 \mathrm{C} \mathrm{mol} / \mathrm{kg}$ in $0-30 \mathrm{~cm}$ layer. The soil $\mathrm{pH}$ and ESP of soil of different treatment plots are presented in Table. The $\mathrm{pH}$ ranged between (7.9 to 9.8) and ESP values had a wide variation (13.5 to 45.6) among the plots with and without gypsum. The treat- 
ments comprised of three levels of gypsum $\left(\mathrm{G}_{0}\right.$-no gypsum, $\mathrm{G},-50 \%$ neutralization of RSC of sodic water with gypsum, $\mathrm{G}_{2}-100 \%$ neutralization of RSC of sodic water with gypsum) and three levels of farm yard manure $\left(\mathrm{F}_{0^{-}}\right.$ no FYM, $F_{1}-10$ t/ha and $F_{2}-20$ t/ha FYM) which were replicated thrice in a randomized block design. Different growth parameters analyzed during the study includes plant height, number of leaves per plant, grading of bulbs, bulb length, bulb dry matter, Total soluble solids (TSS), bulb diameter, seedling mortality (\%), plants survival (\%) at harvest, bulb yield and per cent marketable bulbs. Since the weather components during the season greatly influence the growth, development, yield and quality of the crop considerably, therefore, the data recorded on various meteorological aspects during the course of experimentation from the agro-meteorological station located at Research Farm Department of Agrometeorology, CCS HAU, Hisar are presented in Table 1. Statistical analysis of data collected during the study was done by applying the technique of analysis of variance (ANOVA) as suggested by Gomez and Gomez (1984) and Panse and Sukhatme (1961). All the statistical analysis was carried out by using OPSTAT statistical software.

\section{RESULTS AND DISCUSSION}

\section{Growth and development parameters}

Per cent seedling mortality: The per cent seedling mortality of onion crop was recorded at 15 days after transplanting. Data on seedling mortality per cent clearly revealed that the various levels of FYM and gypsum significantly influenced the per cent seedling mortality (Table 2). The mean value of per cent mortality was 71.61, 43.94 and 36.15 for $G_{0}, G_{1}$ and $G_{2}$ treatments, respectively. The corresponding values were $67.78,47.50$ and 36.43 for $F_{0}, F_{1}$ and $F_{2}$ treatments, respectively. Minimum per cent mortality (18.17) was recorded with $\mathrm{F}_{2} \mathrm{G}_{2}$, whereas, in $\mathrm{F}_{0} \mathrm{G}_{0}$ treatment the maximum per cent mortality (77.50) was observed in $\mathrm{F}_{0} \mathrm{G}_{0}$. Furthermore seedling mortality difference between $\mathrm{G}_{1}$ and $\mathrm{G}_{2}$ was lower than where no gypsum was applied i.e. $\mathrm{G}_{0}$. However, the per cent seedling mortality was found to decrease significantly with increasing level of gypsum and FYM. Application of FYM and gypsum reduced the per cent seedling mortality than in absence of FYM and gypsum. Minimum per cent mortality (18.17) was recorded in $\mathrm{F}_{2} \mathrm{G}_{2}$ treatment whereas in $\mathrm{F}_{0} \mathrm{G}_{0}$ treatment the maximum per cent mortality (77.50) was observed. However, the seedling mortality per cent was found to decrease significantly with increasing level of gypsum and FYM. Application of FYM and gypsum reduced the seedling mortality per cent than in absence of FYM and gypsum. It might be due to the application of gypsum and FYM which minimizes the harmful effect of sodicity and increase nutrient availability as well as better growth conditions. These results are in line with the findings of Yadav et al. (2005) who reported that in case of tomato, maximum numbers of plants (31.0) were survived in treatment where RSC of sodic water was neutralized 100\% and FYM was applied@20t/ha and minimum (0.6) was observed in control plot (without any application of gypsum and FYM).

Plant height: The height of onion was recorded at 30, 60 and 90 days after transplanting (DAT). The mean height of plant at 30 days after transplanting was $31.36,38.11$ and $40.54 \mathrm{~cm}$ for $G_{0}, G_{1}$ and $G_{2}$, respectively, whereas the corresponding values were $32.41,36.80$ and 40.80 for $\mathrm{F}_{0}$, $F_{1}$ and F2 (Table 3), plant height was lowest where no FYM and gypsum was applied. However, plant height increased with increasing levels of FYM and gypsum. Similar trends for plant height were observed at 60 and 90 days after transplanting. Maximum plant height $(51.07 \mathrm{~cm})$ was observed under in $F_{2}(20 \mathrm{t} / \mathrm{ha}$ FYM $)$ treatment and minimum $(40.26 \mathrm{~cm})$ in no FYM treatment at 90 DAT while, in gypsum application, highest plant height (51.06) was recorded with $100 \%$ neutralization of RSC $\left(\mathrm{G}_{2}\right)$ and minimum with no gypsum application. Plant height was increased with increasing level of FYM and gypsum. These results are in accordance with Kaswan et al. (2013) who carried his research on onion and reported that plant height, number of leaves and yields were increased with increasing levels of FYM. The possible reason for this is that FYM increase the fertility as well as provided the favorable environment for growth.

Number of leaves: The mean number of leaves of onion was counted and recorded at 30, 60 and 90 (DAT). The mean number of leaves was at 30,60 and 90 days after transplanting was 4.20, 5.23 and 5.81 for $G_{0}, G_{1}$ and $G_{2}$, respectively. Whereas corresponding values were 4.64, 4.87 and 5.73 for $F_{0}, F_{1}$ and $F_{2}$ (Table 4). The data clearly indicated the number of leaves per plant was lowest (4.07) in $\mathrm{F}_{0} \mathrm{G}_{0}$ and highest (7.02) in $\mathrm{F}_{2} \mathrm{G}_{2}$ treatment at 30 DAT. Moreover the number of leaves per plant also increased significantly with the application of FYM and gypsum. The increase in number of leaves is significantly higher between $\mathrm{G}_{0}$ and $\mathrm{G}_{1}$ and $\mathrm{G}_{0}$ and $\mathrm{G}_{2}$ than between $\mathrm{G}_{1}$ and $G_{2}$. Similar trends were recorded for number of leaves at 60 and 90 (DAT). The maximum number of leaves (8.49) was recorded under combined application of FYM at $20 \mathrm{t} / \mathrm{ha}$ and $100 \%$ neutralization of $\mathrm{RSC}\left(\mathrm{G}_{2}\right)$ while minimum number of leaves was with no FYM and gypsum application at 30,60 and 90 (DAT). These results are in conformity with the finding of Kadlag et al. (2010) who reported that highest number of leaves and plant height in okra (Abelmoschus esculentus L. (Moench) cv. Gujarat Okra-2 was found where application of FYM @ $20 \mathrm{t} / \mathrm{ha}$ was done and this might br due to the reason that more favorable conditions are provided with FYM application which results in better plant growth.

Bulb diameter and bulb length: The diameter of bulbs was recorded after harvesting of onion crop. The mean diameter of onion bulb was 3.81, 4.04 and $4.17 \mathrm{~cm}$ for $\mathrm{G}_{0}, \mathrm{G}_{1}$ and $\mathrm{G}_{2}$ treatments, respectively, and the corresponding values were $3.80,4.01$ and 4.21 for $F_{0}, F_{1}$ and $\mathrm{F}_{2}$ treatments, respectively (Table 5). The data showed the 
Amit Kumar et al. / J. Appl. \& Nat. Sci. 8 (4): 1878-1883 (2016)

Table 1. Mean monthly meteorological data recorded during crop season 2013.

\begin{tabular}{|c|c|c|c|c|c|}
\hline \multirow[t]{2}{*}{ Month and Year } & \multicolumn{2}{|c|}{$\begin{array}{l}\text { Mean atmospheric } \\
\text { perature }\left({ }^{\circ} \mathrm{C}\right)\end{array}$} & \multicolumn{2}{|c|}{ Relative humidity } & \multirow[t]{2}{*}{$\begin{array}{l}\text { Average rainfall } \\
(\mathrm{mm})\end{array}$} \\
\hline & Maximum & Minimum & Morning & Evening & \\
\hline January, 2013 & 17.6 & 4.2 & 95 & 58 & 43.0 \\
\hline February, 2013 & 21.5 & 8.9 & 96 & 60 & 32.7 \\
\hline March, 2013 & 28.4 & 12.0 & 92 & 77 & 31.1 \\
\hline April, 2013 & 35.0 & 17.2 & 68 & 27 & 2.3 \\
\hline May, 2013 & 41.5 & 22.7 & 48 & 17 & 0.0 \\
\hline
\end{tabular}

Table 2. Effect of FYM and gypsum on per cent seedling mortality irrigated with sodic water.

\begin{tabular}{lcccc}
\hline FYM & $\mathbf{G}_{\mathbf{0}}$ & $\mathbf{G}_{\mathbf{1}}$ & $\mathbf{G}_{\mathbf{2}}$ & Mean \\
\hline $\mathrm{F}_{0}$ & 77.50 & 68.33 & 57.50 & 67.78 \\
$\mathrm{~F}_{1}$ & 71.39 & 38.33 & 32.78 & 47.50 \\
$\mathrm{~F}_{2}$ & 65.95 & 25.17 & 18.17 & 36.43 \\
Mean & 71.61 & 43.94 & 36.15 & \\
CD at 5\% & Gypsum $=2.32$ & $\mathrm{FYM}=2.32$ & Gypsum x FYM $=4.04$ & \\
SE (d) & Gypsum $=1.09$ & $\mathrm{FYM}=1.09$ & Gypsum x FYM $=1.88$ & \\
\hline
\end{tabular}

Table 3. Effect of FYM and gypsum on plant height $(\mathrm{cm})$ of onion at different intervals under irrigation with sodic water.

\begin{tabular}{|c|c|c|c|c|c|c|c|c|c|c|c|c|}
\hline \multirow{2}{*}{ FYM } & \multicolumn{4}{|c|}{ 30 DAT } & \multicolumn{4}{|c|}{60 DAT } & \multicolumn{4}{|c|}{90 DAT } \\
\hline & $\mathbf{G}_{\mathbf{0}}$ & $\mathbf{G}_{1}$ & $\mathbf{G}_{2}$ & Mean & $\mathbf{G}_{0}$ & $\mathbf{G}_{1}$ & $\mathbf{G}_{2}$ & Mean & $\mathbf{G}_{0}$ & $\mathbf{G}_{1}$ & $\mathbf{G}_{2}$ & Mean \\
\hline$\overline{F_{0}}$ & 25.27 & 34.20 & 37.77 & 32.41 & 27.73 & 37.93 & 42.13 & 35.93 & 32.06 & 42.26 & 46.46 & 40.26 \\
\hline $\mathrm{F}_{1}$ & 32.80 & 38.53 & 39.07 & 36.80 & 36.67 & 44.47 & 45.17 & 42.10 & 41.00 & 48.80 & 49.50 & 46.43 \\
\hline $\mathrm{F}_{2}$ & 36.00 & 41.60 & 44.80 & 40.80 & 39.27 & 48.07 & 52.90 & 46.74 & 43.60 & 52.40 & 57.23 & 51.07 \\
\hline Mean & 31.36 & 38.11 & 40.54 & & 34.56 & 43.49 & 46.73 & & 38.89 & 47.82 & 51.06 & \\
\hline \multirow{2}{*}{ CD at $5 \%$} & \multicolumn{4}{|c|}{$\begin{array}{l}\text { Gypsum }=1.98 \\
\text { FYM }=1.98\end{array}$} & \multicolumn{2}{|c|}{ Gypsum $=1.82$} & \multicolumn{2}{|c|}{$\mathrm{FYM}=1.82$} & \multicolumn{4}{|c|}{ Gypsum $=2.31 \quad$ FYM $=2.31$} \\
\hline & & \multicolumn{3}{|c|}{ Gypsum x FYM= NS } & \multicolumn{4}{|c|}{ Gypsum x FYM= NS } & \multicolumn{4}{|c|}{ Gypsum x FYM=NS } \\
\hline \multirow{2}{*}{ SE (d) } & & \multicolumn{3}{|c|}{$\begin{array}{l}\text { Gypsum }=0.92 \\
\text { FYM }=0.92\end{array}$} & \multicolumn{2}{|c|}{ Gypsum $=0.85$} & \multicolumn{2}{|c|}{$\mathrm{FYM}=0.85$} & \multicolumn{2}{|c|}{ Gypsum $=1.08$} & \multicolumn{2}{|c|}{$\mathrm{FYM}=1.08$} \\
\hline & & \multicolumn{3}{|c|}{ Gypsum x FYM= 1.60} & \multicolumn{4}{|c|}{ Gypsum x FYM= 1.47} & \multicolumn{4}{|c|}{ Gypsum x FYM=1.87 } \\
\hline
\end{tabular}

Table 4. Effect of FYM and gypsum on number of leaves of onion under irrigation with sodic water at different intervals.

\begin{tabular}{|c|c|c|c|c|c|c|c|c|c|c|c|c|}
\hline \multirow{2}{*}{ FYM } & \multicolumn{4}{|c|}{ 30 DAT } & \multicolumn{4}{|c|}{ 60 DAT } & \multicolumn{4}{|c|}{90 DAT } \\
\hline & $\mathbf{G}_{\mathbf{0}}$ & $\mathbf{G}_{1}$ & $\mathbf{G}_{2}$ & Mean & $\mathbf{G}_{0}$ & $\mathbf{G}_{1}$ & $\mathbf{G}_{2}$ & Mean & $\mathbf{G}_{\mathbf{0}}$ & $\mathbf{G}_{1}$ & $\mathbf{G}_{2}$ & Mean \\
\hline $\mathrm{F}_{0}$ & 4.07 & 4.87 & 5.00 & 4.64 & 5.11 & 5.70 & 5.87 & 5.56 & 5.42 & 6.02 & 6.20 & 5.88 \\
\hline $\mathrm{F}_{1}$ & 4.20 & 5.00 & 5.40 & 4.87 & 5.20 & 5.90 & 6.33 & 5.81 & 5.55 & 6.24 & 6.79 & 6.19 \\
\hline $\mathrm{F}_{2}$ & 4.33 & 5.83 & 7.02 & 5.73 & 5.30 & 6.63 & 8.13 & 6.69 & 5.64 & 6.98 & 8.49 & 7.04 \\
\hline Mean & 4.20 & 5.23 & 5.81 & & 5.20 & 6.08 & 6.78 & & 5.54 & 6.41 & 7.16 & \\
\hline \multirow{3}{*}{ CD at $5 \%$} & \multirow{2}{*}{\multicolumn{4}{|c|}{$\begin{array}{l}\text { Gypsum }=0.31 \\
\text { FYM }=0.31\end{array}$}} & \multicolumn{4}{|c|}{ Gypsum $=0.26$} & \multicolumn{4}{|c|}{ Gypsum $=0.30$} \\
\hline & & & & & FYM= & & & & $\mathrm{FYM}=$ & & & \\
\hline & & \multicolumn{3}{|c|}{ Gypsum x FYM=0.54 } & \multicolumn{4}{|c|}{ Gypsum x FYM=0.46 } & \multicolumn{4}{|c|}{ Gypsum x FYM=0.53 } \\
\hline \multirow{3}{*}{ SE (d) } & & \multicolumn{3}{|c|}{ Gypsum $=0.14$} & \multicolumn{4}{|c|}{ Gypsum $=0.12$} & \multicolumn{4}{|c|}{ Gypsum $=0.14$} \\
\hline & & \multicolumn{3}{|c|}{$\mathrm{FYM}=0.14$} & \multicolumn{4}{|c|}{$\mathrm{FYM}=0.12$} & \multicolumn{4}{|c|}{$\mathrm{FYM}=0.14$} \\
\hline & & \multicolumn{3}{|c|}{ Gypsum x FYM=0.25 } & \multicolumn{4}{|c|}{ Gypsum x FYM=0.21 } & \multicolumn{4}{|c|}{ Gypsum x FYM=0.24 } \\
\hline
\end{tabular}

increasing trends in respect to bulb diameter with increasing level of FYM and gypsum. Minimum mean bulb diameter $(3.81 \mathrm{~cm})$ was recorded in $\mathrm{G}_{0}$ whereas maximum $(4.21 \mathrm{~cm})$ was recorded in $\mathrm{F}_{2}$ treatment. However, the combined effect was non-significant. The mean bulb length was $3.49,3.75$ and $3.89 \mathrm{~cm}$ for $\mathrm{G}_{0}, \mathrm{G}_{1}$ and $\mathrm{G}_{2}$, respectively. Whereas the corresponding values for $\mathrm{F}_{0}, \mathrm{~F}_{1}$ and $\mathrm{F}_{2}$ were $3.55,3.69$ and $3.89 \mathrm{~cm}$, respectively. Further- more, there was a significant increase in bulb length with the application of FYM and gypsum. Bulb length and bulb diameter increased as gypsum and FYM levels increased in $\mathrm{G}_{1}, \mathrm{G}_{2}$ as compared to $\mathrm{G}_{0}$ and $F_{1}$ and $F_{2}$ as compared to $\mathrm{F}_{0}$. The minimum bulb diameter $(3.48 \mathrm{~cm})$ was recorded with no gypsum and no FYM treatment whereas maximum bulb diameter $(4.45 \mathrm{~cm})$ was recorded in $\mathrm{F}_{2} \mathrm{G}_{2}$ i.e. $100 \%$ neutralization of RSC and FYM @ 20 
Amit Kumar et al. / J. Appl. \& Nat. Sci. 8 (4): 1878-1883 (2016)

Table 5. Effect of FYM and gypsum on length and diameter of onion bulb irrigation with sodic water.

\begin{tabular}{|c|c|c|c|c|c|c|c|c|}
\hline \multirow{2}{*}{ FYM } & \multicolumn{3}{|c|}{ Bulb diameter $(\mathrm{cm})$} & \multirow{2}{*}{ Mean } & \multicolumn{3}{|c|}{ Bulb length (cm) } & \multirow{2}{*}{ Mean } \\
\hline & $\mathbf{G}_{0}$ & $G_{1}$ & $\mathbf{G}_{2}$ & & $\mathbf{G}_{0}$ & $\mathrm{G}_{1}$ & $\mathbf{G}_{2}$ & \\
\hline $\mathrm{F}_{0}$ & 3.48 & 3.91 & 4.01 & 3.80 & 3.38 & 3.55 & 3.70 & 3.55 \\
\hline $\mathrm{F}_{1}$ & 3.98 & 4.01 & 4.05 & 4.01 & 3.41 & 3.78 & 3.88 & 3.69 \\
\hline $\mathrm{F}_{2}$ & 3.98 & 4.19 & 4.45 & 4.21 & 3.68 & 3.92 & 4.07 & 3.89 \\
\hline Mean & 3.81 & 4.04 & 4.17 & & 3.49 & 3.75 & 3.89 & \\
\hline CD at $5 \%$ & Gypsum $=0.17$ & $\mathrm{I}$ & 17 & & Gypsum & $\mathrm{F}$ & 4 & \\
\hline SE (d) & Gypsum $=0.07$ & $\begin{array}{r}\text { Gypsu } \\
F \\
\text { Gypsu }\end{array}$ & $\begin{array}{l}M=N S \\
4=0.13\end{array}$ & & $\begin{array}{l}\text { Gypsum } \\
\text { Gypsum }\end{array}$ & $\begin{array}{l}\text { Gypsu } \\
\text { F } \\
=0.11\end{array}$ & & \\
\hline
\end{tabular}

Table 6. Effect of FYM and gypsum on onion yield (q/ha) and per cent marketable bulbs under sodic water irrigation.

\begin{tabular}{|c|c|c|c|c|c|c|c|c|}
\hline \multirow{2}{*}{ FYM } & \multicolumn{4}{|c|}{ onion yield (q/ha) } & \multicolumn{3}{|c|}{ per cent marketable bulbs } & \multirow{2}{*}{ Mean } \\
\hline & $\mathbf{G}_{0}$ & $\mathbf{G}_{1}$ & $\mathbf{G}_{\mathbf{2}}$ & Mean & $\mathbf{G}_{0}$ & $\mathbf{G}_{1}$ & $\mathbf{G}_{2}$ & \\
\hline $\mathrm{F}_{0}$ & 49.27 & 80.00 & 109.00 & 79.42 & 47.10 & 59.27 & 63.75 & 56.71 \\
\hline $\mathrm{F}_{1}$ & 71.70 & 113.50 & 140.00 & 108.40 & 56.15 & 64.90 & 66.00 & 62.35 \\
\hline $\mathrm{F}_{2}$ & 82.77 & 152.22 & 180.83 & 138.61 & 59.17 & 67.62 & 67.75 & 64.84 \\
\hline Mean & 67.91 & 115.24 & 143.28 & & 54.14 & 63.93 & 65.83 & \\
\hline \multirow{2}{*}{ CD at $5 \%$} & \multirow{2}{*}{\multicolumn{3}{|c|}{$\begin{array}{l}\text { Gypsum }=2.79 \quad F Y M=2.79 \\
\text { Gypsum } x \text { FYM }=4.84\end{array}$}} & & \multirow{2}{*}{\multicolumn{2}{|c|}{$\begin{array}{l}\text { Gypsum }=2.18 \\
\text { Gypsum x FYM=3.78 }\end{array}$}} & $\mathrm{FYM}=2.18$ & \\
\hline & & & & & & & & \\
\hline \multirow{2}{*}{ SE (d) } & Gypsum & & $\mathrm{FYM}=1.30$ & & Gypsum = & & $\mathrm{FYM}=1.02$ & \\
\hline & \multicolumn{3}{|c|}{ Gypsum x FYM $=2.26$} & & \multicolumn{3}{|c|}{ Gypsum x FYM=1.77 } & \\
\hline
\end{tabular}

Table 7. Effect of FYM and gypsum on plant survival (\%) at harvest after irrigation with sodic water.

\begin{tabular}{lcccc}
\hline FYM & $\mathbf{G}_{\mathbf{0}}$ & $\mathbf{G}_{\mathbf{1}}$ & $\mathbf{G}_{\mathbf{2}}$ & Mean \\
\hline $\mathrm{F}_{0}$ & 21.94 & 30.28 & 41.83 & 31.35 \\
$\mathrm{~F}_{1}$ & 24.83 & 60.83 & 67.22 & 50.96 \\
$\mathrm{~F}_{2}$ & 32.89 & 75.39 & 81.94 & 63.41 \\
Mean & 26.56 & 55.50 & 63.67 & \\
\hline CD at 5\% & Gypsum $=1.33$ & $\mathrm{FYM}=1.33$ & Gypsum x FYM $=2.30$ & \\
SE (d) & Gypsum $=0.62$ & $\mathrm{FYM}=0.62$ & Gypsum x FYM $=1.07$ & \\
\hline
\end{tabular}

Table 8. Effect of FYM and gypsum on weight of bulbs (kg/plot) of different sizes under sodic water irrigation.

\begin{tabular}{|c|c|c|c|c|c|c|c|c|c|c|c|c|}
\hline \multirow{2}{*}{ FYM } & \multicolumn{4}{|c|}{ Under size $(<40 \mathrm{~g})$} & \multicolumn{4}{|c|}{ Medium size (40-80g) } & \multicolumn{4}{|c|}{ Large size (>80g) } \\
\hline & $\mathbf{G}_{\mathbf{0}}$ & $\mathbf{G}_{1}$ & $\mathbf{G}_{2}$ & Mean & $\mathbf{G}_{\mathbf{0}}$ & $\mathbf{G}_{1}$ & $\mathbf{G}_{\mathbf{2}}$ & Mean & $\mathbf{G}_{\mathbf{0}}$ & $\mathbf{G}_{1}$ & $\mathbf{G}_{2}$ & Mean \\
\hline $\mathrm{F}_{0}$ & 2.61 & 3.28 & 3.95 & 3.28 & 1.69 & 3.00 & 4.95 & 3.21 & 0.63 & 1.79 & 2.00 & 1.48 \\
\hline $\mathrm{F}_{1}$ & 3.14 & 3.98 & 4.80 & 3.98 & 2.99 & 4.81 & 6.02 & 4.61 & 1.03 & 2.58 & 3.30 & 2.31 \\
\hline $\mathrm{F}_{2}$ & 3.37 & 4.93 & 5.83 & 4.71 & 3.73 & 6.73 & 8.05 & 6.17 & 1.14 & 3.55 & 4.20 & 2.96 \\
\hline & 3.04 & 4.07 & 4.86 & & 2.81 & 4.85 & 6.34 & & 0.94 & 2.64 & 3.17 & \\
\hline \multirow{2}{*}{\multicolumn{2}{|c|}{ CD at $5 \%$}} & \multirow{2}{*}{\multicolumn{3}{|c|}{$\begin{array}{l}\text { Gypsum }=0.25 \mathrm{FYM}=0.25 \\
\text { Gypsum x FYM }=0.43\end{array}$}} & \multicolumn{2}{|c|}{ Gypsum $=0.20$} & \multicolumn{2}{|c|}{ FYM $=0.20$} & Gypsun & .27 & \multicolumn{2}{|c|}{$\mathrm{FYM}=0.27$} \\
\hline & & & & & Gypsu & $\mathrm{FYM}=$ & & & \multicolumn{4}{|c|}{ FYM= } \\
\hline \multirow[t]{2}{*}{ SE (d) } & & \multirow{2}{*}{\multicolumn{3}{|c|}{ Gypsum $=0.11 \mathrm{FYM}=0.11$}} & \multicolumn{4}{|c|}{ Gypsum $=0.09$} & \multirow{2}{*}{\multicolumn{4}{|c|}{$\begin{array}{l}\text { Gypsum }=0.12 \quad F Y M=012 \\
\text { Gypsum } \times \text { FYM=0.27 }\end{array}$}} \\
\hline & & & & & \multicolumn{4}{|c|}{ Gypsum x FYM=0.16 } & & & & \\
\hline
\end{tabular}

tha. The bulb length in no FYM and no gypsum treatment was lowest $(3.38 \mathrm{~cm})$ and highest $(4.07 \mathrm{~cm})$ in $F_{2}$ and $\mathrm{G}_{2}$ treatment. The significant increase in bulb length with the application of FYM and gypsum was observed. Increasing level of gypsum and FYM increased the bulb length and bulb diameter. The increase in bulb diameter was due to the amelioration of adverse effect of sodicity by application of FYM and gypsum. Similar findings were also reported by Kaswan et al. (2013) in onion who reported that bulb length, volume of bulb and yield was maximum with increasing level of FYM.

Yield: The onion yield $(\mathrm{q} / \mathrm{ha})$ and per cent marketable bulbs of onion in relation to FYM and gypsum applica- tion irrigated with sodic water is presented in Table 6 . The mean yield with gypsum as well as FYM application showed a significant increasing trend. The yield was 67.91, 115.24 and $143.28 \mathrm{q} /$ ha for $\mathrm{G}_{0}, \mathrm{G}_{1}$ and $\mathrm{G}_{2}$ treatments, respectively. Whereas the corresponding values for $F_{0}, F_{1}$ and $F_{2}$ were $79.42,108.40$ and $138.61 \mathrm{q} / \mathrm{ha}$, respectively. The lowest yield of onion was recorded under $\mathrm{F}_{0} \mathrm{G}_{0}$ which increased significantly with FYM and gypsum application. The per cent marketable bulbs of onion were 54.14, 63.93 and 65.83 for $G_{0}, G_{1}$ and $G_{2}$ treatments, respectively. The corresponding values were 56.71, 62.35 and 64.84 for $\mathrm{F}_{0}, \mathrm{~F}_{1}$ and $\mathrm{F}_{2}$ treatments, respectively. Moreover the minimum per cent marketable 
Table 9. Effect of FYM and gypsum on total soluble solids $\left({ }^{0} \mathrm{~B}\right)$ under irrigations with sodic water.

\begin{tabular}{lcccc}
\hline FYM & $\mathbf{G}_{\mathbf{0}}$ & $\mathbf{G}_{\mathbf{1}}$ & $\mathbf{G}_{\mathbf{2}}$ & Mean \\
\hline $\mathrm{F}_{0}$ & 12.83 & 12.73 & 12.30 & 12.62 \\
$\mathrm{~F}_{1}$ & 12.43 & 11.58 & 11.70 & 11.91 \\
$\mathrm{~F}_{2}$ & 11.98 & 11.37 & 11.27 & 11.54 \\
Mean & 12.42 & 11.89 & 11.76 & \\
\hline CD at 5\% & Gypsum $=0.20$ & $\mathrm{FYM}=0.20$ & Gypsum x FYM $=$ NS & \\
SE (d) & Gypsum $=0.09$ & $\mathrm{FYM}=0.09$ & Gypsum x FYM $=0.16$ & \\
\hline
\end{tabular}

Table 10. Effect of FYM and gypsum on dry matter (\%) of bulbs under irrigation with sodic water.

\begin{tabular}{lcccc}
\hline FYM & $\mathbf{G}_{\mathbf{0}}$ & $\mathbf{G}_{\mathbf{1}}$ & $\mathbf{G}_{\mathbf{2}}$ & Mean \\
\hline $\mathrm{F}_{0}$ & 8.90 & 8.70 & 8.60 & 8.73 \\
$\mathrm{~F}_{1}$ & 8.83 & 8.07 & 8.03 & 8.31 \\
$\mathrm{~F}_{2}$ & 8.68 & 7.93 & 7.82 & 8.14 \\
Mean & 8.81 & 8.23 & 8.15 & \\
\hline CD at 5\% & Gypsum $=0.24$ & $\mathrm{FYM}=0.24$ & Gypsum x FYM $=$ NS & \\
SE (d) & Gypsum $=0.11$ & $\mathrm{FYM}=0.11$ & Gypsum x FYM $=0.19$ & \\
\hline
\end{tabular}

bulbs were recorded under $\mathrm{F}_{0} \mathrm{G}_{0}$ which increased significantly with FYM and gypsum application. Total yield increased significantly with $50 \%$ neutralization $\left(\mathrm{G}_{1}\right)$ and $100 \%$ neutralization $\left(\mathrm{G}_{2}\right)$ compared to $\mathrm{G}_{0}$ where no gypsum was applied. The increase in yield of onion increased with increasing levels of gypsum and FYM. The increase in yield was more with gypsum application than FYM application. This showed the addition of FYM alone is not sufficient to mitigate the harmful effect of sodic water. But in conjunction with gypsum, FYM played a crucial role. The data showed that the yield per plot was lowest in no FYM and no gypsum application and highest in combination of $20 \mathrm{t} / \mathrm{ha} \mathrm{FYM}$ and $100 \%$ neutralization of RSC $\left(\mathrm{F}_{2} \mathrm{G}_{2}\right)$. The yield with gypsum as well as FYM application showed a significant increasing trend. It was observed that the application of $100 \mathrm{~kg} \mathrm{~N}+60 \mathrm{~kg} \mathrm{P}_{2} \mathrm{O}_{5}+60$ $\mathrm{kg} \mathrm{K} 2 \mathrm{O} / \mathrm{ha}$ in association of $400 \mathrm{~kg}$ gypsum/ha gave significantly superior bulbs yield of onion over lower doses of gypsum (Singh et al., 2009). In another study Kaswan et al. (2013) also observed the similar effect of FYM in onion. Minimum per cent marketable bulbs were recorded under no FYM and no gypsum application treatment which increased significantly with FYM and gypsum application.

Plant survival (\%) at harvest: The number of plant survival was recorded at harvest. The mean values for plants survival at harvest were $26.56,55.50$ and 63.67 for $\mathrm{G}_{0}, \mathrm{G}_{1}$ and $\mathrm{G}_{2}$ treatments, respectively. Whereas the corresponding values were $31.35,50.96$ and 63.41 for $F_{0}, F_{1}$ and $F_{2}$ treatments, respectively (Table 7). The plant survival at harvest in $\mathrm{F}_{0} \mathrm{G}_{0}$ treatment was lowest (21.94) and maximum (81.94) in $\mathrm{F}_{2} \mathrm{G}_{2}$ treatment. Furthermore, plant survival at harvest increased significantly with the application of FYM and gypsum. This showed that addition of FYM alone is not sufficient to mitigate the harmful effect of sodic water. But with gypsum, FYM in conjunction played a pivotal role. Plant survival at harvest was lowest $(21.94 \%)$ in no FYM and no gypsum treatment and highest $(81.94 \%)$ in combined application of 20 t/ha FYM and
$100 \%$ neutralization of RSC $\left(\mathrm{G}_{2}\right)$. Plant survival at harvest increased significantly with the application of FYM and gypsum. The similar findings were also observed by Nandal and Bedi (2010) who observed that maximum plant survival at harvest stage was observed with the application of FYM @ 20 t/ha + recommended dose of fertilizers in onion.

Weight of bulbs/plot of different sizes: The grading of bulbs was done after harvest into three categories under size $(<40 \mathrm{~g})$, medium size $(40-80 \mathrm{~g})$ and large size $(>80 \mathrm{~g})$. The mean values for under size $(<40 \mathrm{~g})$ were $3.04,4.07$ and 4.86 for $G_{0}, G_{1}$ and $G_{2}$ treatments, respectively. Whereas the corresponding values were 3.28, 3.98 and 4.71 for $F_{0}, F_{1}$ and $F_{2}$ treatments, respectively (Table 8). Similar increasing trends were observed for medium size (40-80 g) and large size ( $>80 \mathrm{~g})$. The size of bulbs in all the three categories with $\mathrm{F}_{0} \mathrm{G}_{0}$ treatment was lowest (2.61), (1.69) and (0.63) and maximum (5.83), (8.05) and (4.20) with $\mathrm{F}_{2} \mathrm{G}_{2}$ treatment. Furthermore the size of bulbs increased significantly with the application of FYM and gypsum. The bulb weight in all the categories i.e. under size $(<40 \mathrm{~g})$, medium size $(40-80 \mathrm{~g})$ and large size $(>80 \mathrm{~g})$ increased significantly with the application of FYM and gypsum in all the treatments. Increasing trends in medium and large size was also observed. The lowest bulbs weight $(1.69 \mathrm{~kg})$ in medium and large size $(0.63 \mathrm{~kg})$ was recorded in no FYM and no gypsum application treatments and maximum $(5.83 \mathrm{~kg})$ and $(8.05 \mathrm{~kg})$ was with the application of FYM at $20 \mathrm{t} / \mathrm{ha}$ and $100 \%$ neutralization of sodicity $F_{2} G_{2}$. The increase in yield was more with gypsum application than FYM application. These results are in agreement with the findings of Singh et al. (2009) who reported that the maximum shape and size with application of gypsum over control and RDF (recommended dose of fertilizer).

Total soluble solids (TSS) (\%): The total soluble solids of onion crop were recorded at harvest and data are presented in Table 9. The mean TSS values were $12.42,11.89$ and $11.76{ }^{\circ} \mathrm{B}$ for $\mathrm{G}_{0}, \mathrm{G}_{1}$ and $\mathrm{G}_{2}$ treatments, 
respectively. The corresponding values were 12.62, 11.91 and $11.54{ }^{0} \mathrm{~B}$ for $\mathrm{F}_{0}, \mathrm{~F}_{1}$ and $\mathrm{F}_{2}$ treatments, respectively. There was a decreasing trend in TSS with the increasing level of FYM and gypsum. Maximum TSS $\left(12.83{ }^{\circ} \mathrm{B}\right)$ was recorded in $\mathrm{G}_{0}$, whereas, minimum TSS $\left(11.27^{\circ} \mathrm{B}\right)$ in $\mathrm{F}_{2}$ treatment. However, the combined effect was nonsignificant. Furthermore TSS ${ }^{\mathbf{0}} \mathrm{B}$ decreased with increasing levels of FYM and gypsum. Maximum TSS (12.83 ${ }^{0} \mathrm{~B}$ ) was recorded under no FYM and no gypsum application treatments and minimum $\left(11.27{ }^{0} \mathrm{~B}\right)$ TSS was recorded with combined application of FYM at $20 \mathrm{t} /$ ha and $100 \%$ neutralization of RSC $\left(\mathrm{F}_{2} \mathrm{G}_{2}\right)$. However under gypsum application, minimum TSS $\left(11.76^{0} \mathrm{~B}\right)$ was observed in $100 \%$ neutralization of sodicity $\mathrm{G}_{2}$ and maximum $\left(12.42^{0} \mathrm{~B}\right)$ in no gypsum application. The decreasing trends in TSS were observed with the increasing level of FYM and gypsum. This might be due to fact that the gypsum had neutralized the sodicity effect of water and FYM in general improved the physical properties like structure of soil. Similar findings were reported by Yadav et al. (2005) who found that minimum TSS in tomato was observed with combined application of FYM@20 t/ha and $100 \%$ neutralization of RSC $\left(\mathrm{F}_{2} \mathrm{G}_{2}\right)$ and Kaswan et al. (2013) in onion also found the decreasing trend in TSS with increasing level of FYM.

Dry weight: The dry weight of bulbs was recorded after harvesting of onion crop. The mean weight was 8.81, 8.23 and $8.15(\%)$ for $\mathrm{G}_{0}, \mathrm{G}_{1}$ and $\mathrm{G}_{2}$ treatments, respectively. Whereas corresponding values were 8.73, 8.31 and $8.14(\%)$ for $\mathrm{F}_{0}, \mathrm{~F}_{1}$ and $\mathrm{F}_{2}$ treatments, respectively (Table 10). The dry weight of bulbs decreased significantly with the application of gypsum and FYM. However, the combined effects were non-significant. The bulb dry weight was highest $(8.90 \%)$ where no FYM and no gypsum were applied and lowest $(7.82 \%)$ in $\mathrm{F}_{2} \mathrm{G}_{2}$ treatment. Furthermore the decreasing trend in dry weight of bulbs was observed with the application of FYM and gypsum. The minimum values of dry weight under FYM and gypsum was due to neutralization of sodicity. Similar findings were also observed by Yadav et al. (1998) in onion and found that as dry weight of bulbs decreased with decreasing level of salinity.

\section{Conclusion}

From the study, it was observed that the maximum seedling mortality per cent was recorded where no FYM and no gypsum were applied and minimum was with FYM when applied @20 t/ha and 100\% neutralization of RSC. Maximum increase in plant height, number of leaves per plant, bulb length, bulb diameter, bulb yield, plants survival at harvest, per cent marketable bulbs and bulb size were observed in $100 \%$ neutralization of RSC and FYM (a) $20 \mathrm{t} /$ ha application while, minimum increase in plant height, number of leaves per plant, bulb length, bulb diameter, bulb yield, plants survival at harvest, per cent marketable bulbs and bulb size .(including all grades viz. under size, medium size and large size bulbs) were in no FYM and no gypsum treatment. Combined application of FYM and gypsum minimizes the adverse effect of sodic water and improve the soil properties also. Moreover, in the Quality parameters of onion, the highest TSS was observed under no FYM and no gypsum application and minimum TSS was in FYM at 20 t/ha and $100 \%$ sodicity was neutralized by gypsum application application. Maximum bulb dry mater was observed in no FYM and gypsum application treatment while minimum was in FYM at $20 \mathrm{t} / \mathrm{ha}$ and $100 \%$ sodicity was neutralized by gypsum application.

\section{REFERENCES}

Anonymous (2009). A report of the expert group of the indian council of medical research. National Institute of Nutrition, Hyderabad.

Tiwari, R.K., Mistry, N.C., Singh, B. and Gandhi, C.P. (2013). Indian horticulture database. Government of India, pp. 80-81

Minhas, P.S. and Samra, J.S. (2004). Waste water use in peri -urban agriculture, Impact and opportunities. Tech. Bull. No. 2, CSSRI, Karnal.

Gomez, K.A. and Gomez, A.A. (1984). Statistical. Procedure. for Agricultural. Research., $2_{\text {nd }}$ ed. John Wiley and Sons, New York, USA.

Panse, V.G. and Sukhatme, P.V. (1961). Statistical Methods for Agricultural Workers. Indian Council of Agricultural Research, New Delhi, India, 381 p.

Yadav, A.C., Sharma, S.K. Singh, A., and Kapoor, A and Lal, S. (2005). Effects of high RSC water along with FYM and gypsum in tomato variety Hisar Arun. In: Proceeding of the National symposium of Diversification of Agriculture through Horticultural crops, Feb 21-23 at Karnal p, 114-116

Kaswan, P.K., Yadav, P.K. and Sharma, B.D. (2013). Response of onion (Allium cepa L.) varieties to farm yard manure in arid region of western Rajasthan. Ann. of Hortic., 6(1): 30-34

Kadlag, R.R., Kapadiya, P.B., Chandore, H.D. and Joshi, M.D. (2010). Effect of organic, inorganic fertilizer and biofertilizers on growth of okra. Haryana J. of Hortic. Sci., 39(3/4): 316-317

Singh, D.P., Prakash, H.G. and Dabbas, M.R. (2009). Response of gypsum application with agro-chemical on onion (Allium cepa L.) in alluvial tract of Uttar Pradesh. Asian J. Hortic., 4(2): 510-511

Nandal, T.R. and Bedi, M.K. (2010). Integrated nutrient management studies in onion (Allium cepa L.) under low hills sub-tropical conditions of Himachal Pradesh. Crop Res. Hisar, 40(1/3): 113-116

Yadav, S.S., Singh, N. and Yadav, B.R. (1998). Effect of different levels of soil salinity on growth and yield of onion (Allium cepa). Indian J. Hortic., 55(3): 243-247 